\section{ORJINAL MAKALE}

(D) Cemil Ișilk Sönmez ${ }^{1}$

(D) Duygu Ayhan Bașer ${ }^{2}$

Gülcan Uluda $\breve{g}^{1}$

Hülya Kara ${ }^{1}$

Ahmet Peker ${ }^{1}$

Kağan Tașkaya ${ }^{1}$

Elif Çalık ${ }^{1}$

Hacer Serin ${ }^{1}$

Zeynep Aybikem Sağlam ${ }^{1}$

D Barıs Can Arici ${ }^{1}$

Selda Dursun ${ }^{1}$

(D) Erkan Nefesoğlu ${ }^{1}$

${ }^{1}$ Düzce Üniversitesi, Tıp

Fakültesi, Aile Hekimliği AD,

Düzce, Türkiye

${ }^{2}$ Hacettepe Üniversitesi Tip

Fakültesi, Aile Hekimliği AD,

Ankara, Türkiye

\section{Yazıșma Adresi:}

Duygu Ayhan Başer

Hacettepe Üniversitesi Tip Fakültesi. Aile Hekimliği AD, Ankara, Türkiye Tel: +90 5056645210

E-mail:duyguayhan@outlook.com

Gelis Tarihi: 25.03.2019

Kabul Tarihi: 01.05.2019

DOI: $10.18521 / \mathrm{ktd} .581944$
Konuralp Medical Journal e-ISSN1309-3878

konuralptipdergi@duzce.edu.tr konuralptipdergisi@gmail.com www.konuralptipdergi.duzce.edu.tr

\section{Düzce Üniversitesi Aile Hekimliği Polikliniğine Başvuran Erişkin Hastaların Acile Başvurma Nedenleri ve İliş̧kili Faktörler \\ ÖZET}

Amaç: Çalışmanın amacı birinci basamak sağlık hizmetlerine başvurmuş ve son altı ayda acil başvurusu bulunan hastaların profilini ve yapılan başvuruların amacını, niteliğini ve gerçek anlamda aciliyet gerektirip gerektirmediğini ortaya koymak, hastaların poliklinik yerine acil servisi tercih etme nedenlerini belirlemektir.

Gereç ve Yöntem: Tanımlayıcı nitelikte bir araştırmadır. Bir üniversitenin Aile Hekimliği Polikliniğine 2019 Mart ayı içerinde başvuran ve dâhil olma ve dışlama kriterleri ile uyumlu olan ve son altı ayda acil servise başvurmuş olan erişkin hastalar çalışmanın örneklemini oluşturmuştur. Tarafımızca hazırlanan veri toplama formu hastalara tarafımızca uygulanmıştır.

Bulgular: 150 hasta çalışmaya dâhil olmuştur. Katılımcıların \%62'si kadın, \%38'i erkekti. Hastaların son 6 ayda acile başvuru ortalamaları 2,45'idi. Hastaların \%67,3'ü akşam ve gece saatlerinde başvurmuş, \%92'si kendi imkânı ile gelmiş, \%91,3'ü taburcu olmuş; \% 5 ,4'üne yatı̧ verilmişti. Hastaların en sık başvuru nedeni ÜSYE idi. Hastaların poliklinik yerine acili tercih etme nedenleri sorgulandığında büyük çoğunluğu mesai saatleri nedeniyle ve zamanı kısıtlı olduğu için acili tercih ettiklerini belirtmişlerdir.

Sonuç: Çalışma sonucunda hastaların acili tercih etme nedenleri; acile uygunsuz başvuruların sayılarını artıran nedenler olarak karşımıza çıkmaktadır. Bu durumda uygun triaj sistemlerinin acillerde bulunması uygunsuz başvuru sayısını azaltabilir. $\mathrm{Bu}$ aşamada birinci basamak sağllk hizmetlerinin devreye girmesi acil üzerindeki yükü azaltabilir.

Anahtar Kelimeler: Acil Servis, Aile Hekimliği, Başvuru, Erişkin

\section{Application Reasons of Adult Patients Admitted to the Family Medicine Outpatient Clinic of Düzce University and Related Factors \\ ABSTRACT}

Objective: The aim of study is to determine the profile of patients who applied to primary health care services(PHCS) and who have applied to the emergency department(ED) in last six months, the purpose, quality of applications, whether the applications require urgency or not and the reasons why patients prefer ED instead of PHCS.

Methods: This is a descriptive study. The study sample consisted of adult patients who applied to Family Medicine Policlinic of a university in March 2019 and who met the inclusion and exclusion criteria and applied to the ED in the last six months. Data collection form prepared by us was applied to patients by us.

Results: 150 patients were included in study. $62 \%$ of the participants were female and $38 \%$ were male. In last 6 months, the mean admission number was $2.45 .67 .3 \%$ of the patients applied in the evening and night hours, $92 \%$ came with their own means, 91.3\% were discharged; $5.4 \%$ had been hospitalized. The most common reason for admission was UTI. When questioning the reasons of prefer ED instead of PHCS, most of patients stated that they prefer ED because of working hours and time is limited.

Conclusions: As a conclusion, the reasons for patients to choose ED emerged as reasons increasing the number of inappropriate applications to the ED. In this case, the presence of appropriate triage systems in EDs may reduce the number of inappropriate applications. At this stage, the use of PHCS can reduce the burden on the EDs.

Keywords: Emergency Services, Family Medicine, Applications, Adult 


\section{GíRiş}

Acil servisler, her türlü acil hasta ve yaralıların bakıldığı hastanelerin en önemli birimlerinden birisidir. Acil serviste hizmet alan hastalara en kisa sürede müdahale edilmesi birincil amaç olarak hedeflenmektedir. Acil olmayan ve basit-hafif şikâyetleri olan hastaların da poliklinikler yerine acil servisi tercih etmeleri, aşırı hasta yoğunluğuna sebep olarak gerçek acil olan hastaların tanı alma süresini ve tanı alsa dahi müdahale süresini uzatmakta olduğu gözlemlenmektedir. Bunun yanı sıra hizmet kalitesinin düşmesine de yol açmaktadır. $\mathrm{Bu}$ konuda hastaların düzenli izlem ve tedavilerinin yapılabildiği birinci basamak sağlık hizmetlerinin kullanımının yaygınlaşması ve acil olmayan başvuruların azaltılmasına yönelik olarak birinci basamak sağlık hizmetlerinin güçlendirilmesi bir alternatif olarak düşünülebilir (1-5).

Hastalar pek çok nedenle acil servislere daha çok başvuru yapmaktadırlar. Yapılan çalışmalarda bu nedenler; sağlık hizmetine en hizlı ve kolay yoldan ulaşma isteği, daha hızlı tetkik yaptırma ve tedavi olabilme düşüncesi gibi nedenler belirtilmiştir (6-8).

$\mathrm{Bu}$ konuda hastaların düzenli izlem ve tedavilerinin yapılabildiği birinci basamak sağlık hizmetlerinin kullanımının yaygınlaşması ve acil olmayan başvuruların azaltılmasına yönelik olarak birinci basamak sağlı hizmetlerinin güçlendirilmesi bir alternatif olarak düşünülebilir.

Yapilan literatür taramasinda acil başvurularının değerlendirmesine yönelik çalışmaların retrospektif yada acil başvuruları üzerinden yapıldığı görülmüştür (3-9). Birinci basamak hastalarının acil deneyimleri ile ilgili bir çalışmaya rastlanmamıştır. Çalışmanın dizaynının avantaj1 verilen retrospektif değil direk hastadan alınması ve hastaların acil gibi stres altında değil daha rahat bir ortamda ve daha objektif olarak anketi doldurabilecek olmasıdır. Bu nedenlerle; bu araştırmamızın amacı birinci basamak sağlık hizmetlerine başvurmuş ve son altı ayda acil başvurusu bulunan hastaların profilini ve yapılan başvuruların amacını, niteliğini ve gerçek anlamda aciliyet gerektirip gerektirmediğini ortaya koymak, hastaların poliklinik yerine acil servisi tercih etme nedenlerini belirlemek olarak belirlenmiştir.

\section{MATERYAL VE METOD}

Çalışma tanımlayıcı nitelikte bir epidemiyolojik araştırmadır. Düzce Üniversitesi Aile Hekimliği Polikliniğine 2019 Mart ayı içerinde başvuran ve son altı ayda acil servise başvurmuş olan erişkin hastalar çalışmanın evrenini oluşturmuştur. Evrenden dahil olma ve dışında tutulma kriterleri ile uyumlu olan, ankete katılmayı kabul eden hastalar ise çalışmanın örneklemini oluşturmuştur. Örneklem sayısı belirlenmeksizin bu ay süresince Düzce Üniversitesi Aile Hekimliği Polikliniğine gelen tüm hastalara ankete katılmaları teklif edilmiş ve kabul eden kişilerle çalışma yürütülmüştür. Toplamda 1020 başvuru olmuş bu kişilerden son altı ayda acil başvurusu olduğunu bildiren 193 kişiden 150'si çalışmaya katılmayı kabul etmiştir. Çalışmaya dâhil etme ve dışlama kriterleri Tablo 1 de sunulmuştur.

Tablo 1. Çalışmaya dahil olma dışlama kriterleri Dahil olma kriterleri:

1.18 yas ve üzeri olmak

2.Araştırmaya katılmayı gönüllü olarak kabul etmek

3.Son 6 ay içerisinde acil servise başvurmuş olmak

Dışında olma kriterleri:

1.18 yaşından daha küçük olmak

2.Çalışmaya katılmayı kabul etmemek

3.Anket formunu eksik doldurmak

Katılımcıların demografik özellikleri ve acil servise başvuruları hakkındaki bilgilere yönelik tarafimızca hazırlanan 15 soruluk veri toplama formu hastalara tarafimızca uygulanmıştır. Anket sorularından 1 tanesinde katılımciların en son acil başvurduklarındaki aciliyet durumlarını kendilerine göre 1'den 5'e puanlamaları istenmiştir (1=Acil değil, 5=Çok acil). Bu skala Kanada 5'li troyan skalası baz alınarak oluşturulmuştur.

Çalışmadan elde edilen verilerin istatistiksel analizinde grup karşılaştırmaları için verilerin dağılım şekline bağlı olarak Independent samples t test veya Mann-Whitney $U$ test ile One-Way ANOVA veya Kruskal-Wallis testlerinin kullanılmıştır. Kategorik değişkenler arası ilişkiler uygun çapraz tablo istatistikleriyle, sürekli değişkenler arası korelasyonlar ise verilerin dağılım şekline uygun korelasyon analizleri ile incelenmiştir

\section{BULGULAR}

Katılımcıların \%62'si (n=93) kadın, \%38'i $(n=56)$ erkekti. Hastaların yaş ortalaması 41,61 $\pm 16,936$ (min:18; max:80) idi. Katılımcıların $\% 40,7$ 'si $\quad(n=61)$ çalışmiyor; \%19,3'ü $\quad(n=29)$ öğrenciydi. \%65,3 (n=98)'ünün sosyal güvencesi SGK, \%54 (n=81) 'ünün geliri gidere eşitti. Hastaların sosyodemografik özellikleri Tablo 2'de verilmiştir. Hastaların acile başvuru ortalamaları 2,45 $\pm 2,160$ (min:1; max:15) idi. Acilde kalış süresi ortalamaları 2,43 $\pm 3,813$ (min: 1; max: 31) saat idi. Hastaların \%43,3 (n=65)'ü akşam, \%24'ü $(n=36)$ gece saatlerinde acile başvurmuştu. Hastaların \%92 (138)'si acile kendi imkânı ile gelmiş, \%91,3 $(n=137)$ 'ü taburcu olmuş; \%3,3 $(n=5)$ 'ü sevk edilmişti. Hastaların \%5,4'üne yatış verilmiştir; yatış verilen hastaların büyük çoğunluğunun sabah saatlerinde geldiği $(\% 37,5) ; \% 62,5$ 'inin ambulans ile geldiği ve $\% 87,5$ 'unun acil durum skorlamas1 olarak kendine 4 ve üzeri puan verdiği görüldü. Tanı olarak yatış yapılan hastaların \%25'inin karın ağrısı tanısı aldığı görüldü. 
Tablo 2. Hastaların sosyodemografik özellikleri

\begin{tabular}{|c|c|c|}
\hline & Sayı (n) & Yüzde (\%) \\
\hline \multicolumn{3}{|l|}{ Cinsiyet } \\
\hline Kadın & 93 & 62 \\
\hline Erkek & 56 & 38 \\
\hline \multicolumn{3}{|l|}{ Yaş } \\
\hline 20 yaş altı $(<20)$ & 17 & 11,3 \\
\hline $20-39$ & 63 & 42,0 \\
\hline $40-65$ & 55 & 36,7 \\
\hline 65 üstü $(65<)$ & 15 & 10,0 \\
\hline \multicolumn{3}{|l|}{ Meslek } \\
\hline Çalışmıyor & 61 & 40,7 \\
\hline İşçi & 15 & 10,0 \\
\hline Memur & 11 & 7,3 \\
\hline Serbest Meslek & 15 & 10,0 \\
\hline Emekli & 19 & 12,7 \\
\hline Öğrenci & 29 & 19,3 \\
\hline \multicolumn{3}{|l|}{ Eğitim durumu } \\
\hline Okuryazar Değil & 9 & 6,0 \\
\hline Okuryazar & 41 & 27,3 \\
\hline İlkokul & 32 & 21,3 \\
\hline Ortaokul & 15 & 10,0 \\
\hline Lise & 33 & 22,0 \\
\hline Üniversite & 20 & 13,3 \\
\hline \multicolumn{3}{|l|}{ Sosyal güvence } \\
\hline SGK & 98 & 65,3 \\
\hline Emekli sandığı & 17 & 11,3 \\
\hline Bağkur & 22 & 14,7 \\
\hline Yeșilkart & 5 & 3,3 \\
\hline Yok & 8 & 5,3 \\
\hline \multicolumn{3}{|l|}{ Gelir durumu } \\
\hline Gelir Giderden Az & 40 & 26,7 \\
\hline Gelir Gidere Eşit & 81 & 54,0 \\
\hline Gelir Giderden Çok & 29 & 19,3 \\
\hline TOPLAM & 150 & 100 \\
\hline
\end{tabular}

Hastaların en sık başvuru nedeni \%24,7 $(n=37)$ sinin başvuru nedeni olan ÜSYE idi. Bunu eklem ağrısı, alt batın ağrısı ve İYE, gastrointestinal şikâyetler takip etmekteydi. Hastaların acile başvuru nedenleri tablo 3 'te verilmiştir.

Tablo 3. Hastaların acile başvuru nedenleri

\begin{tabular}{lll}
\hline & Sayı (n) & Yüzde (\%) \\
\hline ÜSYE & 37 & 24,7 \\
\hline Eklem ağrısı & 15 & 10,0 \\
\hline Göğüs ağrısı & 5 & 3,3 \\
\hline Gastrointestinal şikâyetler & 13 & 8,7 \\
\hline HT & 6 & 4,0 \\
\hline İYE, alt batın ağrısı & 15 & 10,0 \\
\hline Kırık, çıkık & 11 & 7,3 \\
\hline Baygınlık, panik atak & 8 & 5,3 \\
\hline Baş ağrısı & 9 & 6,0 \\
\hline Nefes darlığı, astım atak & 8 & 5,3 \\
\hline Ateş & 5 & 3,3 \\
\hline Diğer & 18 & 12,0 \\
\hline Toplam & 150 & 100,0 \\
\hline
\end{tabular}

Hastalara durumlarının aciliyetliklerinin 1 'den 5'e skorlamaları istendiğinde skor ortalaması $3,27 \pm 1,356$ olarak saptand. Hastaların \% 26,7 $(\mathrm{n}=40)$ 'si durumunun 3 değerinde acil olduğunu, $\% 22,7(\mathrm{n}=34)$ ' si 4 derecede acil olduğunu, \%23,3 $(n=35)$ 'ü 5 derecede acil olduğunu düşünmekteyken; \%13,3 (n=20)'ü durumunun 1 derecede acil olduğunu düşünmekteydi. Hastaların durumlarının aciliyetini değerlendirme skorlamaları grafik 1'de verilmiştir.

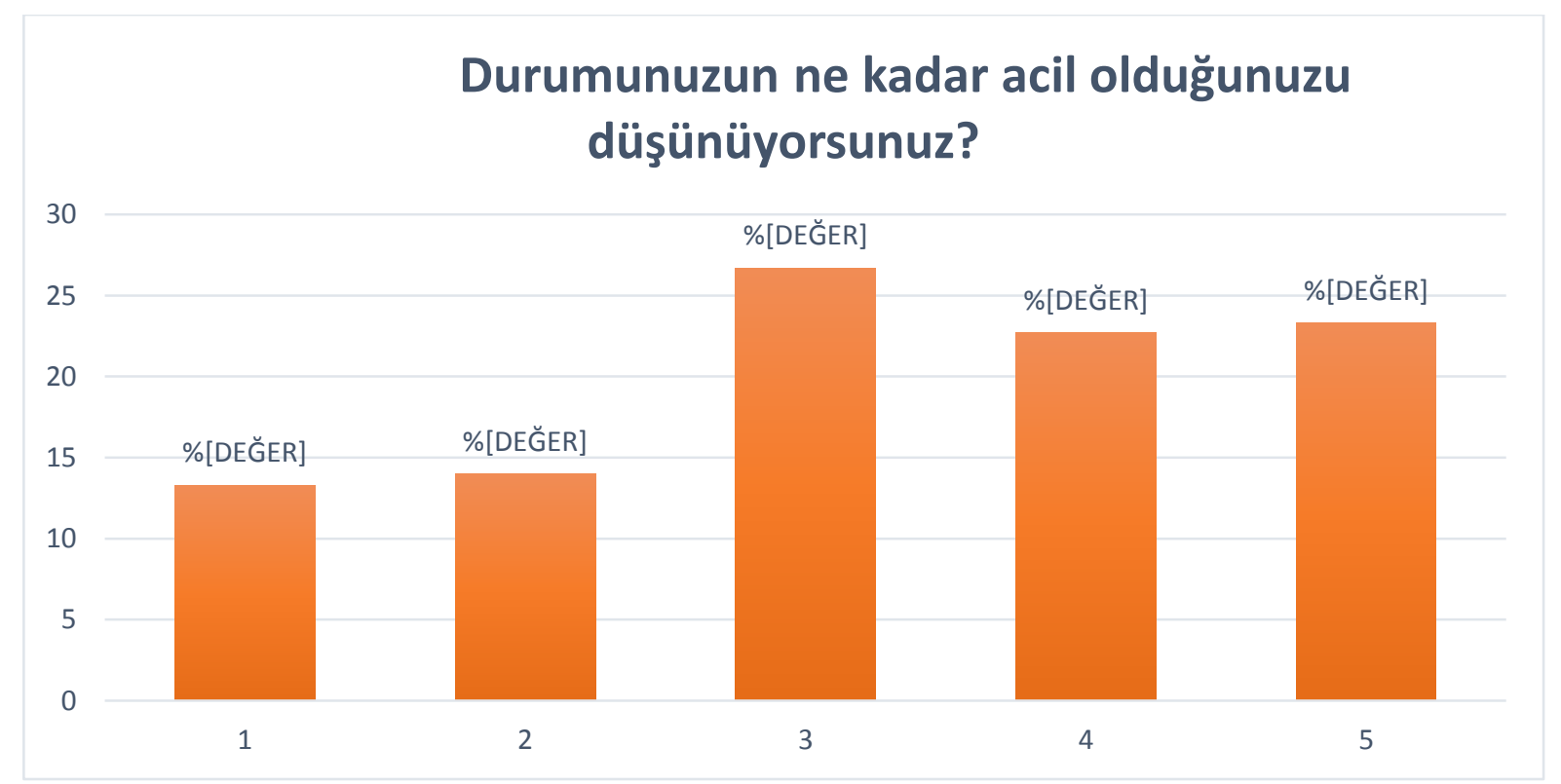

Grafik 1. Hastaların durumlarının aciliyetini değerlendirme skorlamaları 
Hastaların yaş arttıkça acile başvuru durumlarını skorlama değerlerinin arttığı ve bu artışın istatistiksel olarak anlamlı olduğu görüldü $(\mathrm{p}<0,000)$. Hastaların acile geliş saatlerine göre durumlarının acile başvuru durumlarının skorlama değerleri ile karşılaştırılması yapıldığında sabah gelenlerin \%50'sinin 1-5 puan skalasından 5 puanı seçtikleri, öğle gelenlerin skor dağılımlarının ağırlıklı yığılma göstermediği, akşam gelenlerin \%55,4'ünün 4 ve üstü puan verdiği, gece gelenlerin ise $\% 55,5$ 'inin 4 ve üstü puan verdiği görüldü. Hastaların kendi durumlarına verdikleri aciliyet puanları ile acile geliş saatleri karşılaştırıldığında istatistiksel olarak anlamlı ilişki olduğu ve sabah ve gece gelenlerin 4 ve üstü puan daha çok verdikleri görüldü (p:0,042). Hastaların acile geliş saatlerine göre durumlarının kendilerine göre acillik skorları karşılaştırılması Grafik 2’de görülmektedir.

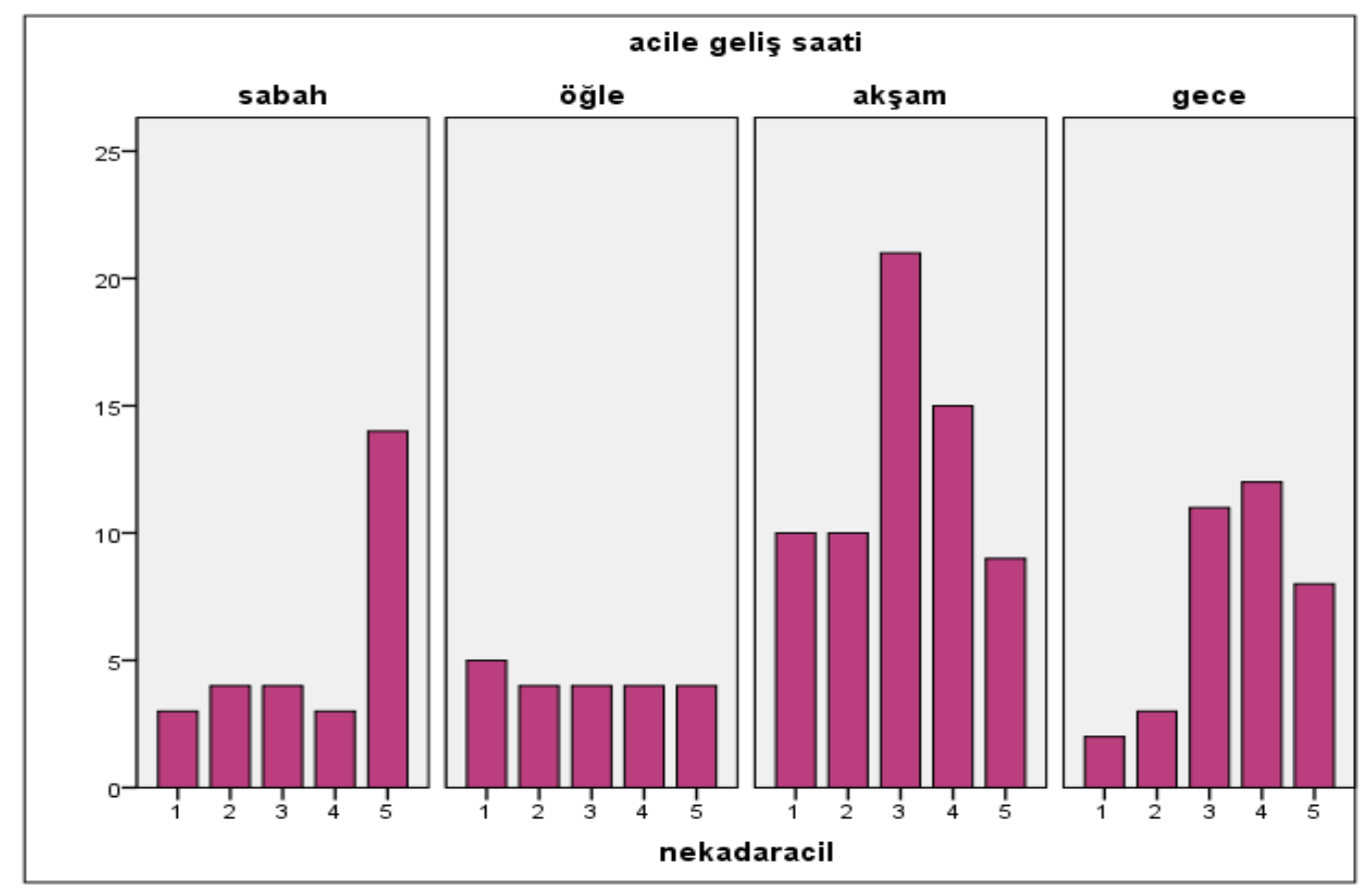

Grafik 2. Hastaların acile geliş saatlerine göre durumlarının kendilerine göre acillik skorlarının karşılaştırılması

Hastaların acile geliş saatleri ile cinsiyet, meslek, eğitim durumu, sosyal güvence durumu, gelir düzeyi, geliş nedeni ve sonuç arasında istatistiksel olarak anlamlı bir ilişki görülmemiştir $(\mathrm{p}<0,05)$.

Hastaların tedavilerinin sonlanış şekilleri ile acile nasıl geldikleri karşılaştırıldı̆̆ında ambulans ile gelenlerin daha çok yatış aldığı, kendi imkânları ile gelenlerin ise daha çok sevk edildiği ve bu ilişkinin istatistiksel olarak anlamlı olduğu görülmüştür $(\mathrm{p}<0,000)$. Acilde kalış süresi arttıkça da tedavilerin daha çok yatış ve sevk yönünde sonuçlandığ 1 ve acilde kalış süresi ile tedavi sonuçlanması arası ilişkinin istatistiksel olarak anlamlı olduğu görüldü $(\mathrm{p}<0,000)$.

Cinsiyet, eğitim, meslek değişkenlerinin acile son 6 ayda başvuru sayısı, başvuru nedeni, başvuru saati, acile geliş şekli, acilde kalış şekli ve tedavinin sonlanış şekli ile karşılaştırılması yapıldığında istatistiksel bir fark yaratmadı $\breve{g} 1$ görüldü $(p>0,05)$. Yaşa göre değerlendirildiğinde ise yaş arttıkça acile başvuru sıklığının arttığı ve bu durumun istatistiksel olarak pozitif yönde anlamlı olduğu görüldü (t:0,013; p: 0,047).

Hastalara poliklinik yerine acili tercih etme nedenleri sorgulandığında hastaların \%35,3 $(\mathrm{n}=53)$ 'ü mesai saatleri nedeniyle, \%25,3 $(n=38)$ ' ü enjeksiyon yada serum yaptırabilmek için ve $\% 20,7$ (n=31)'si zamanı kısıtlı olduğu için acili tercih ettiklerini belirtmiştir. Hastaların poliklinik yerine acili tercih etme nedenleri Tablo 4'te verilmiştir.

Tablo 4. Hastaların poliklinik yerine acili tercih etme nedenleri

\begin{tabular}{lcc}
\hline & Sayı (n) & Yüzde (\%) \\
\hline Zamanım kısıtlı olduğu için & 31 & 20,7 \\
\hline Mesai saatleri nedeniyle & 53 & 35,3 \\
\hline $\begin{array}{l}\text { Polikliniklerde randevu } \\
\text { bulamadığım için }\end{array}$ & 29 & 19,3 \\
\hline $\begin{array}{l}\text { Acildeki tedavilere daha çok } \\
\text { güvendiğim için }\end{array}$ & 8 & 5,3 \\
\hline $\begin{array}{l}\text { Enjeksiyon veya serum } \\
\text { yaptırabilmek için }\end{array}$ & 38 & 25,3 \\
\hline Rapor yazdırabilmek için & 3 & 2 \\
\hline $\begin{array}{l}\text { Daha düşük ücretli } \\
\text { olduğunu düşündüğüm için }\end{array}$ & 5 & 3,3 \\
\hline $\begin{array}{l}\text { Ulaşım imkanı daha kolay } \\
\text { olduğu için }\end{array}$ & 20 & 13,3 \\
\hline Tahlil yaptırabilmek için & 9 & 6 \\
\hline Daha hızlı sonuç almak için & 55 & 36,7 \\
\hline
\end{tabular}




\section{TARTIŞMA}

Acil başvurularının değerlendirilmesi sağlık hizmetlerindeki düzenlemenin yapilabilmesi açısından büyük önem taşımaktadır. Bu çalışmada birinci basamak sağlık hizmetlerine belirli bir sürede başvuran bir grup hasta son 6 aylık süredeki acil başvuruları ve başvurularının içeriği açısından değerlendirilmiştir.

Çalışmaya katılanların değerlendirilmesi yapıldığında; çalışmamızda birçok çalışmaya benzer oranda kadın oranı daha fazla olarak bulunmuştur $(7,8)$. Bazı çalışmalarda ise erkek başvurularının daha fazla olduğundan bahsedilmektedir $(9,10)$. Çalışmalarda belirtilen acil başvurularındaki cinsiyet dağılımındaki bu farkın nedeni; acil servis hizmetlerinin yürütüldüğü bölge ile ilişkili olabilir. İş merkezlerine fabrikalara yakın bir acilde erkek başvurusu daha çok olabilecekken; daha merkezi toplu yaşam alanlarına yakın bir bölgenin acil servisinde kadın ve çocuk başvuru sayısının daha çok olabileceği ön görülmektedir.

Son 6 ayda acil başvurusunda bulunan hastalar yaş dağılımına göre incelendiğinde ise yaş ortalamasının 41,61 $\pm 16,936$ olduğu ve grup olarak da en çok 20-40 yaş hasta grubunun başvuru yaptığı görüldü. Çalışmaya erişkin hastalar dahil edildiği için genel acil başvuruları üzerinden değerlendirme yapılan çalışmalarla karşılaştırma yapılmadı. Erişkin hastalar üzerinden değerlendirme yapılan çalışmalarla ise benzerlik olduğu ve diğer çalışmalar gibi 20-40 yaş aralığında başvuru sayısının arttığı görülmüştür (3).

Acilde kalış süresi ortalamaları 2,5 saat idi. Kılıçaslan ve arkadaşlarının çalışmasında ise acil serviste hastaların ortalama kalış süresi iki saat olarak belirtilmiştir (4) Amerikan Acil Tip Derneğinin raporuna göre ise ciddi olmayan hastalık veya yaralanma durumlarında ortalama kalış süresi 1-2 saat olarak belirtilmiştir (11). Oktay ve arkadaşlarının çalışmasında bu süre 3,3 saat olarak (7); ABD'de verilerine göre ise 3.2 saat olarak verilmiştir (12). Hastanın acilde kalış süresinin hastanın acile tekrar başvurusu, gelecek başvurularında poliklinik yerine acili tercih etmesi gibi durumlar üzerine önemli bir etkisi vardır. Çalışmamızdan elde edilen sonuç ulusal ve uluslararası çalışmalarla benzerlik göstermektedir.

Çalışmamızda hastalara durumlarının aciliyetliklerini 1'den 5'e skorlamaları istendiğinde skor ortalaması 3 olarak saptandı. Hastaların yarısından fazlası durumlarının 4 ve üzeri ciddiyette olduğunu belirtmişti. Hastaların yaşları arttıkça acile başvuru durumlarını skorlama değerlerinin arttığı görüldü. Hastaların acile geliş saatlerine göre durumlarının acile başvuru durumlarının skorlama değerleri ile karşılaştırılması yapıldığında sabah, akşam ve gece gelenlerin yarısından fazlasının 4 ve üstü puan verdiği görüldü yani çalışmamızda yaş ve acile geliş zamanının kişilerin durumlarının aciliyetlerine verdikleri skorlarla ilişkili faktörler olduğu görüldü.
Çalışmamızda hastaların \%43,3'ü akşam, \%24'ü gece saatlerinde acile başvurmuştu. Köse ve arkadaşlarının çalışmasında acile en çok başvuru saatinin sabah ve öğle olduğu (13), Kilıçaslan ve arkadaşlarının çalışmasında akşam saatlerinde (4), Aydın ve arkadaşlarının çalışmasında da sabah ve öğle saatlerinde (9), Hastalık Kontrol ve Önleme Merkezi'nin verilerine göre ise, en yoğun saatler sabah saatleri olan sabah ve akşam olarak belirtilmiştir (14). Çalışmalarda sabah saatlerindeki yoğunluk ortak olarak belirtilse de diğer zaman aralıkları çalışmalara göre farklılık göstermektedir. Bundaki en önemli etmen acil servisin bulunduğu şehir, bölge vb şartların hasta profilini direk etkiliyor olmasıdır. Hastanemiz şehir merkezine yakın bir üniversite hastanesi olması nedeni ile acil polikliniklerde her saat yoğunluk olmakta bunun yanısıra üniversite hastanesi olması nedeni ile sevklerin de çok fazla yapılması nedeni ile yoğunluğu hiç azalmamaktadır. Hastaların başvuru saatlerini etkileyecek diğer faktörlerin (yaş, meslek durumu vb) her çalışmadaki farklı örneklem nedeni ile çeşitlilik göstermesi sonuçların farklı gelmesi açısından olağandır.

Çalışmamızda hastaların acile en son başvuru şikayetleri açısından değerlendirme yapıldığında başvuruların en sık ÜSYE nedenli olduğu, bunu eklem ağrısı, alt batın ağrısı ve İYE, gastrointestinal şikâyetlerin takip ettiği görüldü. Acil başvuruları üzerinden yapılan diğer çalışmalarda en sık başvuru nedeninin çeşitlilik gösterdiği bazı çalışmalarda solunum yolu problemleri (15) olarak belirtilirken baz1 çalışmalarda ise gastrointestinal sistem rahatsızlıkları (6), bazı çalışmalarda ise karın ağrısı, baş ağrısı $(4,13)$ olarak belirtildiği görülmüştür.

Yapılan birçok çalışmada acil servisten yatış oranları \%4-13 arası rapor edilmiştir; bizim çalışmamızda bu oran \%5,4 tür $(3,4,7,9)$. Köse ve arkadaşlarının çalışmasında hastaların en fazla karın ağrısı ve üst solunum yolu hastalıkları tanılarla acil gözleme yatış olduğu belirtilmiştir (13); çalışmamızda da benzer şekilde yatış alan hastaların en sık aldığı tanı karın ağrısı olarak belirtilmiştir. Karın ağrısı tanı sürecinde takip isteminin olabildiği ve yatarak takip gerekebilen yada eğer akut batın vb tanılara dönerse kesin yatış verilmesi gereken bir ön tanı olması nedeni ile genel yatış alan hastalar arasında yüksek oranlarda saptanmış olabilir. Yine çalışmamızda yatış alan hastaların özellikleri incelendiğinde büyük çoğunluğunun ambulans ile hastaneye geldiği ve kendi aciliyet durumları için yüksek puanlar verdiği görülmüştür. $\mathrm{Bu}$ durumda hastalar aslında acile başvurmadan kendi aciliyet durumlarının farkında oldukları söylenebilir. $\mathrm{Bu}$ durumda kendi gözlemleri doğrultusunda eğer aciliyet görmedikleri bir durum varsa acil yerine genel polikliniklere yada birinci basamak sağlık hizmetlerine 
başvurmaları acil yoğunluğunu azaltabilecek bir hamle olabilir.

Çalışmamızda acile ambulans ile gelenlerin daha çok yatış aldığı ve acilde kalış süresi arttıkça da tedavilerin daha çok yatış ve sevk yönünde sonuçlandığı görülmüştür. Acil servise ambulansla başvuran hastaların aciliyetinin retrospektif değerlendirildiği bir çalışmada başvuruların \%62,3'ünün acil olduğu ve acil vakaların hastaneye yatış oranının anlamlı bir şekilde yüksek bulunduğu belirtilmiştir (16).

Hastalara poliklinik yerine acili tercih etme nedenleri sorgulandığında hastaların \%36,7'si daha hızlı sonuç almak için, \%35,3 ‘ü mesai saatleri nedeniyle, \%25,3'ü enjeksiyon yada serum yaptırabilmek için ve \%20,7'si zamanı kisıtlı olduğu için acili tercih ettiklerini belirtmiştir. Yapılan çalışmalarda ise; sağlık hizmetine en hızlı ve kolay yoldan ulaşma isteği, daha hızlı tetkik yaptırma ve tedavi olabilme düşüncesi gibi nedenler belirtilmiştir (6-8). Bu nedenler acil başvurularında uygun bir başvuru için geçerli sebepler olmamakla birlikte acile uygunsuz başvuruların sayılarını arttıran nedenler olarak karşımıza çıkmaktadır. Bu durumda uygun triaj sistemlerinin acillerde bulunması uygunsuz başvuru sayısını azaltabilir.

$\mathrm{Bu}$ çalıma aile hekimliği polikliniğine gelen ve son 6 ayda acil başvurusu olan hastalar üzerinde yapılmıştır; çalışmanın acil şartlarında yapılmamış olmasının bu konuda avantaj ve dezavantajları bulunmaktadır. Avantajları hastaların acil şartlarında ankete geri dönüş oranlarının az olabilme ihtimali, sağlık durumlarındaki sıkıntı nedeni ile soruları tam nitelikli cevaplama ihtimallerinin azalabilmesi ve o şartlarda objektif bir değerlendirme yapamama ihtimalleridir. Dezavantajları ise acil başvurusu sonrası geçen sürenin anketi yanıtlarken hafiza etkisi nedeniyle cevaplardaki güvenilirliği azaltabilme etkisi olabilir.

\section{SONUÇ}

Çalışma sonucunda hastaların acili tercih etme nedenleri; acile uygunsuz başvuruların sayılarını arttıran nedenler olarak karşımıza çıkmaktadır. Bu durumda uygun triaj sistemlerinin acillerde bulunması uygunsuz başvuru sayısını azaltabilir. Ancak triaj polikliniklerinin iyi yapılanması acil için uygun olmayan hastalar için iyi yapılanmış bir sevk yada yönlendirme sistemlerinin olması gerekmektedir. Bu aşamada birinci basamak sağlık hizmetlerinin devreye girmesi ve acil için uygunsuz olan hastaları gerekli yönlendirmelerle yönetimlerinin gerçekleştirilmesi acil üzerindeki yükü azaltabilir. Hastaların zaman problemleri için uygun çözümler bakanlık tarafından gerçekleştirilecek gerekli politikalarla da yapılandirılabilir.

\section{KAYNAKLAR}

1. Derlet RW, Kinser D, Ray L, et al. Prospective İdentification And Triage Of Nonemergency Patients Out Of An Emergency Department: A 5-Year Study. Ann Emerg Med 1995;25(2):215-23.

2. Polat O, Kabaçam G, Güler İ, et al. İbn-İ Sina Hastanesi Acil Servis'ne Başvuran Hastaların Sürveyans Analizi. Türkiye Acil Tıp Dergisi 2005;5(2):78-81.

3. Ersel M, Karcıoğlu Ö, Yanturalı S, et al. Bir Acil Servisin Kullanım Özellikleri Ve Başvuran Hastaların Aciliyetinin Hekim Ve Hasta Açısından Değerlendirilmesi. Türkiye Acil Tıp Dergisi 2006;6(1):25-35.

4. Kılıçaslan İ, Bozan H, Oktay C, et al. Türkiye'de Acil Servise Başvuran Hastaların Demografik Özellikleri. Türkiye Acil Tıp Dergisi 2005;5(1):5-13.

5. Andrulis DP, Kellermann A, Hintz EA, et al. Emergency Department And Crowding İn United States Teaching Hospitals. Ann Emerg Med 1991;20(9):980-6.

6. Edirne T, Edirne Y, Atmaca B, et al. Yüzüncü Yıl Üniversitesi Tıp Fakültesi Acil Servis Hastalarının Özellikleri. Van T1p Dergisi 2008;15(4):107-11.

7. Oktay C, Cete Y, Eray O, et al. Appropriateness Of Emergency Department Visits İn A Turkish University Hospital. Croat Med J 2003;44(5):585-91.

8. Pereira S, Oliveira Silva A, Quintas M, et Al. Appropriateness Of Emergency Department Visits İn A Portuguese University Hospital. Ann Emerg Med 2001;37(6):580-6.

9. Aydın T. Aydın ŞA, Köksal Ö, et al. Uludağ Üniversitesi Tıp Fakültesi Hastanesi Acil Servisine Başvuran Hastaların Özelliklerinin Ve Acil Servis Çalışmalarının Değerlendirilmesi. Akademik Acil Tıp Dergisi 2010; 9(4); 163- 8.

10. İncesu E, Beylik U, Küçükkendirci H. Acil Servis Sağlık Hizmetlerinde Başvuru Tekrarı Sorunu: Türkiye’de Bir Devlet Hastanesi Acil Servis Araştırması. Akademik Bakış Dergisi 2016;53: 1-19.

11. URL:Www.Acep.Org Fact Sheets. Emergency Department Waiting Times: American College Of Emergency Medicine.

12. American College Of Emergency Medicine. Measures To Deal With Emergency Department Overcrowding. Ann Emerg Med 1990; 19: 944-5.

13. Köse A, Köse B, Öncü MR, Tuğrul F. Bir devlet hastanesi acil servisine başvuran hastaların profili ve başvurunun uygunluğu. Gaziantep Tıp Derg 2011;17(2): 57-62.

14. McCaig LF, Burt CW. National Hospital Ambulatory Medical Care Survey: 2002 emergency department summary, Adv Data 2004;340:1-34. 
15. Özşaker E, Demirkorkmaz F, Dölek M. Acil servise başvuran yaşlı hastaların bireysel özelliklerinin ve başvuru nedenlerinin incelenmesi. Türk Geriatri Dergisi 2011; 14(2):128-34.

16. Yaylacı S, Cimilli Öztürk T, Çelik Yılmazer S. Acil Servise Ambulansla Başvuran Hastaların Aciliyetinin Retrospektif Değerlendirilmesi. Acıbadem Üniversitesi Sağlık Bilimleri Dergisi 2013; 4(2): 64-7. 